\title{
Thomas Grillot
}

\section{A World of Knowledge}

\section{Recreating Lakota Horse Effigies}

I met Wallace "Butch" Thunder Hawk on a baseball diamond in Mandan, North Dakota, in 2017. His team's jerseys were imprinted with a warrior on horse of his own design. At the Indian technical college where he teaches art, at a local fair where he sold drawings inspired by ledger art, in the pamphlets announcing funerals that a local undertaker serving Native American families liked to adorn with Indian designs, at the local historical society, I came across Butch and his art. Though a fixture of the rather informal local "tribal art" scene, he once told me: "People say I'm famous, but I'm not," While he never reached the status of artists Oscar Howe or Arthur Amiotte, his role models, he is a recognized authority on Lakota art and culture, and representative of a category of locally respected Native artists that staff tribal colleges and have enjoyed some recognition at the national level. Butch's productions have been exhibited in his home state of North Dakota, but also at Thomas Jefferson's home in Virginia, at the Nelson-Atkins Museum in Kansas, and Harvard's Peabody Museum.

Butch's itinerary could be understood as the making of a local career in traditional Native American arts and crafts. ${ }^{1}$ A full reconstitution of this itinerary, and of the specific and nonspecific travails of becoming a tribal artist, however, is outside of the scope of this article. Here, I want to focus on a specific piece that Butch started making in the 1990s: the horse memorial effigy. Such effigies were once carved out of cottonwood branches by Butch's ancestors to honor the memory of a horse of theirs that was wounded or killed in battle. These sticks were exhibited during dances, and even ridden on. ${ }^{2}$ Butch now makes these effigies for museums and horse owners, both Lakota and non-Lakota. His total output is not much more than twenty pieces. Yet his production gives a fascinating insight into the institutional and social framework

1 The phrase "arts and crafts" has been in use since the passing of the Indian Arts and Crafts Act of 1935, to carve out (and defend) a specifically "Indian” domain in the art world. "Tribal art," while clearly embedded in colonial history, is the term by which Butch's work is most often referred to; it is "tribal art" that Butch teaches at United Tribes. His own reluctance to self-define other than as a Lakota should come out clearly from the next paragraphs, as should his working in a world traversed by such categories. For a discussion of tribal art, see in particular Janet Catherine Berlo and Ruth B. Phillips, Native North American Art (New York: Oxford University Press, 2015 [1998]).

2 On horse effigies, see Splendid Heritage: Masterpieces of Native American Art from the Masco Collection, commentary by Arthur Amiotte, John C. Ewers, Richard A. Pohrt, and others (Santa Fe: Wheelwright Museum of the American Indian, 1995), esp. 110; Ian M. West, "Tributes to a Horse Nation: Plains Indian Horse Effigies," South Dakota History, 9, no. 4 (1978), 291-302, "Plains Indian Horse Sticks," American Indian Art 3, no. 2 (1978), 58-67; and E. M. Maurer, ed., Visions of the People: A Pictorial History of Plains Indian Life (Seattle: The University of Washington Press, 1992), 168. 
that made it possible for him to give contemporary relevance to a practice that, for all intents and purposes, had died somewhere in the mid-twentieth century with the warriors who had once ridden horses on the battlefield. Hailing from Cannonball, the same community on the Standing Rock reservation where Butch was born, No Two Horn was one such warrior. This cousin of Sitting Bull's and veteran of the battle of Little Big Horn (1876) is an avowed inspiration for Butch, but not a master in the traditional sense. Butch, who was born in 1946 and is not a direct descendant of No Two Horn's, never studied under him-as No Two Horn died in 1942. This means that Butch's making of horse effigies is neither absolute recreation, nor clearly inherited practice. Nor can it be said to display only "traditional" knowledge acquired in the confines of family or community.

The point I want to make here is that it took, in fact, a world of knowledge for Butch to restart the practice of horse effigies, and this world of knowledge was really a world of relations. By this I don't simply mean that Butch could not have done it on his own or that the knowledge he drew on implied more than technical skill. The designation "tribal art" is, after all, already predicated on the idea that the tribal artist represents his community, and with it his "culture," "tribe," and "ancestors.” By world, I mean a combination of social settings that cannot be restricted to home, reservation or tribe, and that made it possible for Butch to acquire, display, claim, enact knowledge, and eventually give it the shape of a "horse effigy." It is Butch's access to those social spaces throughout his life that his effigies bring to light. Not the lost world of a warrior culture, but the world, very much alive, in which "tribal art" has come to be recognized as a branch of "art" in general.

To approach the making of knowledge in the practice of "tribal art," I want to use conversations Butch and I have had on his career in 2017 and 2019 as well as various newspaper articles, press releases, publications, museum archives, and a more general understanding of social relations on and off Standing Rock, the Lakota/ Dakota reservation where Butch is an enrolled member and where I've been conducting field research for the past ten years. On the one hand, this paper is a historical study, emphasizing the role of major developments in museology, legislation, and the art market. On the other hand, it is an attempt to approach, through reconstitution rather than direct observation, the collective and continued production of "tribal art" in the United States. My focus is not on techniques or discourse on art. Rather, I propose to identify social interactions that made "horse effigies" possible, and pinpoint the knowledge embedded in these interactions, by which I mean not simply information, nor the fact that knowledge was a condition of these interactions, but the very production of knowledge through them. Mine therefore is an attempt to approach indirectly the processes of knowledge production that were available to Butch throughout his training and career, as they are visible in his own declarations as well as the paper trail his work has produced.

When I first asked Butch to reminisce on his career, I was especially interested in the training he might have received from his own relatives. How, I wondered, were 
art and the transmission of art and crafts-related knowledge shaped by family ties; how, in turn, did they shape these ties? This line of questioning elicited two different types of answers. Butch was clearly willing to explore with me the decisive role of some, but not all of his relatives: raised by his maternal grandparents and his parents, he especially emphasized the role of the former. But although they were themselves artists and craftspeople, he was too young when he lived with them to learn more from them than a certain way of life, an outlook on Lakota cultural practices or an attitude toward work and family. His maternal grandparents, however, had friends who were also bearers of traditional knowledge that ranged from songs and crafts to plants, horses, and history. Many practitioners who taught him much were friends, relatives, and neighbors of his ascendants. Butch, in other words, had inherited connections, and with them, an opportunity to learn. Exploring his own background, Butch was thus quick to pay homage to all the elders in the Cannonball district of the Standing Rock reservation whom he had met while growing up. His answers took the shape of a list of names, associated with specific skills that he learned from these neighbors. Less richly recounted than his connection with his grandparents, these relations appeared more specialized, centered on the acquisition of distinct bits of knowledge, the making of a certain item, the learning of a dying or tanning technique. It seemed as though Butch had neatly progressed from a general, social and moral indoctrination with his relatives to a more technical, almost professional training with these neighbors.

This only half true. Discussing his career with him, it becomes apparent that each stage of his trajectory saw the intertwining of different types of learning processes, but that the making of relationships was always a prime concern of his career-that, in other words, technical knowledge was always immersed in and second to social connections and social skills. Before drawing up a list of teachers, Butch emphasized long-term association with his home community of Cannonball, and the sheer multiplicity of individuals from which he learned how to make such and such object or element of traditional knowledge. This emphasis on connections need not immediately be understood as typically "Lakota," although there is a large consensus, both in the literature and among reservation dwellers of all backgrounds, that Lakota people place special emphasis on at least family connections. ${ }^{3}$ It'd be more precise to explain Butch's own emphasis on connections by his personal itinerary. As for many Standing Rockers born in the 1940s, Butch's is an itinerary of migration. Although he spent a good part of his childhood on the reservation, he wasn't born there and did not live there exclusively, but instead moved between Cannonball, the nearby cities of Mandan and Bismarck, and Los Angeles. Making his family's connections and ties

3 A succinct but influential statement of this view is to be found in Ella Deloria, Speaking of Indians (Lincoln: University of Nebraska Press, 1998 [1944]); see also Raymond J. DeMallie, Teton Dakota Kinship and Social Organization, PhD diss. (University of Chicago, 1971). 
to the reservation into learning experiences involved going back and forth between several locales off of it and Cannonball, rather than merely drawing on an original experience there. In a very concrete sense for Butch, learning was thus first and foremost about maintaining connections to a place he first left early as a child and where he stopped living after he came of age. Being an "off reservation Indian" implied a specific relational "work.” Maintaining connection despite long distance and separation, however, was not new to Lakotas and Butch could draw on collective experience to remedy these problems.

Already on the reservation, the acquisition of "traditional" knowledge was closely connected for Butch to the practice of exchanging visits with other families, eating and singing with them-an essential social moment in the making and remaking of connections for all Standing Rockers. Visiting almost always involved some kind of direct indoctrination in doing things "the Indian way": showing proper deference to elders and parents, displaying the appropriate table manners, singing the appropriate songs. It was also marked by a large degree of informality. Children were expected to learn by ear and sight rather than by asking questions or sitting waiting to be taught. Today, many aging citizens of Standing Rock bemoan the fact that they did not sufficiently "pay attention" during those interactions. Butch did, as he liked spending time with older people. Learning was for him about seizing the opportunity to be around these "old timers" and getting from them what they were willing to share-as well as, little by little, learning to ask questions and listening intently, with no other aid than his own senses. Although each elder he cited during our interviews had their specialty, the learning was never confined to "arts and crafts" (carving, beading, tanning, etc.) but marked by a more general emphasis on making connection with the land, animals, and ancestors, with the same attention to propriety that governed relationships between elders and children. Learning was very much a physical experience also: collecting pigments and wood in the hills or the bottom lands by the Missouri River, processing hides, singing, dancing. A total experience, learning was above all a social one-with society expended to nonhumans and the land.

What's more, visiting often constituted a preparation for larger social functions, such as powwows. By the time Butch reached teenage, powwows, or social gatherings centered on the performance of Native American dances, were happening all over the US, both on and off reservations. Following his grandparents and parents, Butch was able early on to extend the sphere of his observations beyond the confines of family and community. His world encompassed an Indian network connecting practitioners of singing and dancing, encouraging the making of dancing outfits, regalia, and other pieces as a way to preserve techniques and a way of life, but also as a means to take part in the nascent powwow circuit or sell art to tourists. Far from limiting him to specialized, reservation-bound interactions, his connection to singers, dancers, and other practitioners of Lakota arts and crafts trained him to navigate between the distinct but connected social settings, on and off the reservation. Unsurprisingly, perhaps for one who now defines his work as "tribal art," the most specific "tribal" 
training Butch received in childhood was in the art of living in a Lakota and Indian world, in the midst of the US.

At first sight, the contrast couldn't seem starker between this type of diffuse, rather informal, very socialized learning and the one Butch became familiar with in public and Bureau of Indian Affairs (BIA)-sponsored schools he attended until he graduated from high school in 1964. Classroom and classmates, textbooks and curricula: those were an entirely different learning environment. Yet getting a degree and teaching is precisely what made it possible for Butch to develop his art and his knowledge of his elders' techniques and processes. Although Butch got to know most of the elders he cites in his childhood, he makes clear that he visited them again, and more intently, in his twenties and thirties, when he himself was already teaching, in high school and at a technical college.

Both universes (academia and life with family and friends) were strongly connected. The first connection was sports. Throughout middle school, high school, and college, it was sports that drove attendance in school for Butch as for many of his contemporaries. The son of a semi-professional baseball player, Butch went a step further than the rest by going to college in North Dakota on a sports scholarship, majoring in physical education and coming back to the reservation to coach.

This, however, proved to be a mere stepping stone in getting a more formal artistic education: only a couple of years after graduating, he went back to school to attend the California College of Arts and Crafts in Oakland, where he perfected his knowledge of graphic design. He was then hired at United Tribes Technical College (UTTC) in Bismarck, North Dakota. As an illustrator and a historian working for the American Indian Curriculum Development, a program started in 1972 to teach Native American cultures in the classrooms of North Dakota, Butch reopened his connections to Cannonball artists and craftspeople, participating in the creation of an archive of interviews with them that he's been using himself ever since. This position allowed him to slowly build his reputation and move on to a position of tribal art instructor, still his current job at the time I last interviewed him (in 2019). Classroom teaching and practice, in other words, have been crucial to turning his practice of Lakota crafts into more than a hobby. They have, in particular, strongly reinforced his omnivorous approach to art. A strong example would be his practice of traditionally female crafts such as beading, tanning, or parfleche making. ${ }^{4}$ First developed to address the need to teach both male and female students, these skills are now part of Butch's résumé and figure prominently on his business card. Classrooms, clearly, were more than a

4 Although one should not overemphasize the gendered specialization of crafts on the plains. On this, see Mary Jane Schneider, “Women's Work: An Examination of Women's roles in Plains Indian Arts and Crafts," in The Hidden Half: Studies of Plains Indian Women, ed. P. Albers and B. Medicine (Washington, DC: University Press of America, 1983), 101-22. 
setting to pass on information. Teaching started a second period of learning for Butch, a second socialization as a Lakota, this time as a Lakota teacher and artist.

The various forms of learning that Butch experienced in this academic setting were no less bound up in social interactions than they were in a non-academic milieu. Some differences with his learning experiences as a child and teenager are obvious. He used new tools, such as the tape recorder; money came more visibly into play, in cash or kind, as a reward or an incentive to elders for sharing their knowledge; and students were part of the transactions, physically or as an invisible presence, the ultimate objective of Butch's visiting with elders. Some knowledge made it to print in small booklets used mostly in Native American schools, which listed patterns, recipes, and processes; ${ }^{5}$ some never left archival repositories; some were immediately put to use by Butch and his students. These new ways of eliciting, producing, and storing knowledge tied in with older ways, however. They, in fact, increased the need for Butch to make use of the social skills he acquired in childhood: not all elders took kindly to the use of the tape recorder; not all made clear what they wanted as compensation. For himself and his students, or for the non-Indians interested in Lakota culture he chaperoned on the reservation, Butch had to draw on his sense of appropriateness and decorum, and appreciate what could make it to the record and what would remain oral knowledge. The teaching he imparted, like that he received, was itself not confined to technicalities, but steeped in a more general appreciation of how to do things properly, the Lakota way. Always, technical specifications were mixed with a more general description of the old "Indian way of life."

If there was change, it was not from a socialized, diffuse learning to a more focused, classroom-based one, but more toward learning about tradition from within Indian institutions. It is from within United Tribes that Butch developed his view of the way knowledge about arts and crafts had been transmitted in the past and should be transmitted in the future. Butch's emphasis on his own community as the source of his knowledge was strongly influenced by the context of the 1970s, during which he started working at United Tribes. At that time elders and "old timers" were increasingly defined as sources of fast disappearing knowledge. Teaching material based on their knowledge invariably gestured toward a lifestyle more intimately connected with "the land," inviting Native American readers to not to lose that connection.

Inevitably, these naturalized practices that had already been entangled in the workings of the market and the art world throughout his grandparents' lifetime. In our interviews as well as in declarations he made as early as the $1970 \mathrm{~s},{ }^{6}$ Butch insisted that in the old days, everyone was a craftsperson, or that arts and crafts were part

5 For example: Plains Indian Crafts, Tools, Weapons, and Handicrafts from Nature (United Tribes of North Dakota Development Corporation, 1975), UTTC Archives.

6 See for example, "Butch Thunder Hawk," a one-page presentation in the AICDP records of UTTC Archives. 


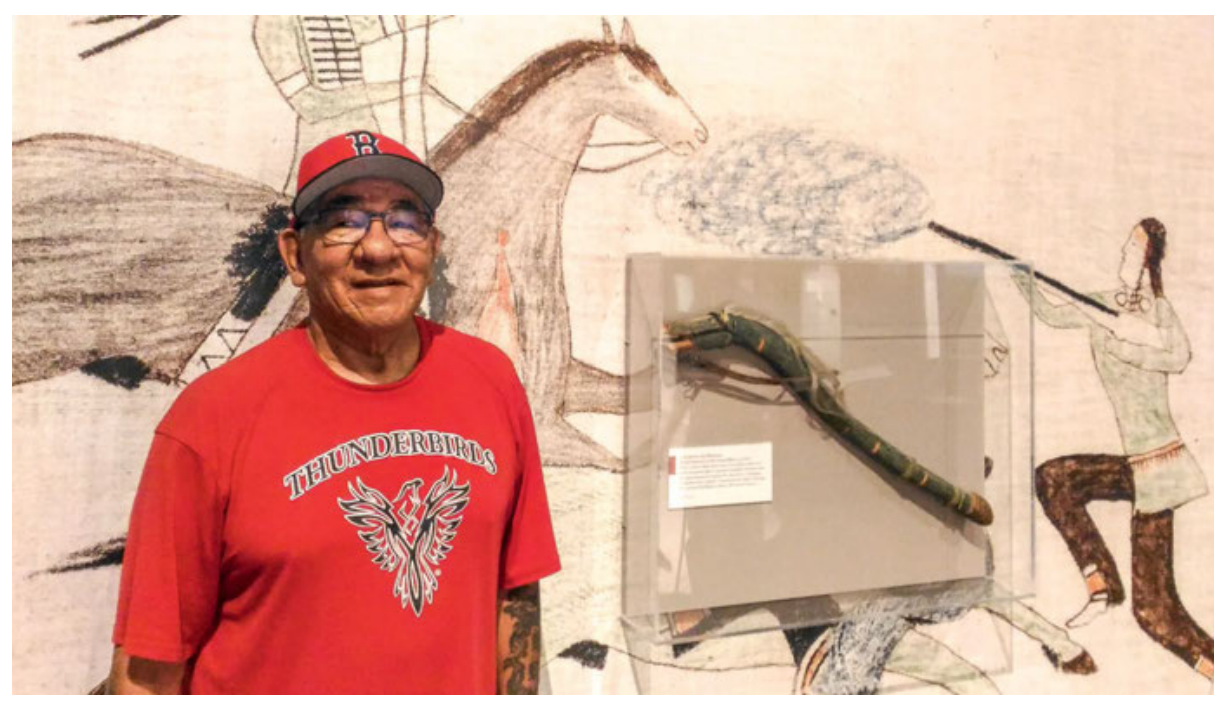

Fig. 1: Butch Thunder Hawk at the North Dakota State Museum, in front of one of No Two Horn's horse memorial effigies.

of life and not a distinct sphere of human activity. This view, no doubt strongly felt, tends to erase the fact that, since the 1900s, certain mediations had become important to the making of Lakota arts and crafts, shaping certain individuals' specialization. Opportunities had developed on and near reservations that fostered the preservation and the evolution of Lakota crafts. From fairs to collectors to Indian traders and railroads and small tribal enterprises, practitioners of old Lakota techniques could expect to complement their revenue by selling a variety of handmade objects and pieces of outfit. At the railroad station in Mandan, where Indian dancing was demonstrated, a small trade of Native articles existed throughout the first part of the twentieth century. Dakotas from the Cannonball area made articles (decorated canes, parfleches, beadwork in various forms, moccasins, hide clothing) specifically for the market-and made them repeatedly. ${ }^{7}$ While Native craftspeople continued to produce for their own and their family's consumption, especially for dancing and ceremonial

7 On tourism, museums, and Lakota art, see Marsha C. Bol, "Defining Lakota Tourist Art, 1880-1915," in Unpacking Culture: Art and Commodity in Colonial and Postcolonial Worlds, Ruth Phillips and Christopher Steiner, eds. (Berkeley: University of California Press, 1999), 214-28; Deirdre Evans-Pritchard, "The Portal Case: Authenticity, Tourism, Traditions, and the Law," Journal of American Folklore 100 (1987): 287-96; Raymond J. DeMallie, Royal B. Hassrick, and Glenn E. Markoe, Vestiges of a Proud Nation: The Ogden B. Read Northern Plains Indian Collection (Burlington, VT; Hull Fleming Museum; 1986); on the involvement in the market of Butch's neighbors, see Richard Green, "Yanktonai Beadwork and Other Souvenir Items from Cannon Ball Community, North Dakota," Whispering Wind 33, no. 3 (2015): 10-12. 
purposes, the market was now the destination for a large number of items. Many a specialization was encouraged by market demand. This was the case for Butch's grandparents, and for the man whose work inspired Butch to craft horse effigies: No Two Horn (fig. 1). ${ }^{8}$

These marketplace interactions also made it possible for Butch to learn more about his ancestors' craft in adulthood through an institution he became familiar with by teaching: the museum. The market did more than just encourage Lakota artists to produce, and produce more than, in all likelihood, they would have without it. It ultimately transferred Lakota art from reservations to museums, making it available for study. In the 1980s, Butch looked at three horse effigies by No Two Horn before starting making his own. One had first been owned by a priest, the other by a taxidermist, a third by a US senator, who had bought them between the 1910s and the 1940s. ${ }^{9}$ In North Dakota as elsewhere, many collectors behaved as small museum owners, devoting entire rooms of their houses or even separate buildings to their collection. But often this did not last: most ended up giving away or selling their collections to local and national museums. Butch's own first contact with the museum in Bismarck was as a teenager in grade school. He renewed this connection as a teacher once at United Tribes. Visits with students and conversations with curators at the Heritage Center became a standard practice for him, as he was granted access not just to the displays but also to the museum's reserve collections and files. Getting access as a teacher to old pieces whose makers had passed away turned out to be an entirely new way of getting and producing knowledge, one, again, that supposed combining various types of skills-social, technical, and, as well shall see, spiritual. It also required a new transformation from Butch, one that took him to a new status as artist-cum-expert-a status he does not claim but has been granted nonetheless by several institutions. This followed transformations of the art world which, by the 1980s, elevated many new Native objects to art status and made more common Native American artists and specialists' collaboration with museums.

Butch's recounting of his itinerary does not really illuminate this institutional part of his own story. It is, however, essential to the emergence of his project to recreate horse effigies after No Two Horn's example. While they had been collected and exhibited in several museums before the 1970s, horse effigies acquired status as works of art only (rather than mere curio or ethnographic material) in the second part of that decade. The institutional and intellectual configuration that made this pos-

\footnotetext{
8 On Joseph No Two Horns (1852-1942), see David Wooley and Joseph D. Horse Capture, "Joseph No Two Horns (He Nupa Wanica),” American Indian Art Magazine 18, no. 3 (Summer 1993): 32-43.

9 This information is taken from the Heritage Center's accession forms for its three horse effigies by No Two Horn. For a book chapter discussing the role of a local collector as an intermediary between Standing Rock and eastern institutions, see Barbara A. Hail, "Museums as Inspiration: Clara Endicott Sears and the Fruitlands Museums," in Collecting Native America: 1870-1960, Shepard Krech III and Barbara A. Hail, eds. (Washington, DC: Smithsonian Institution,1999), 232-58., esp. 184-86.
} 
sible is worth detailing, especially the exhibition that first advertised a horse effigy as an example of Native American artistry. In 1976-77, Sacred Circles: Two Thousand Years of North American Indian Art showcased 670 Native pieces first in London and then in Kansas City, at the Nelson-Atkins Museum. ${ }^{10}$ As the exhibition's catalog made clear, the purpose was to demonstrate Native American art's universal value, indeed its equal dignity on the art world scene with other, more anciently celebrated examples of artistic ingenuity. The first page of the introduction explicitly singled out a particular piece for admiration, rhetorically asking its reader: "does not the unique Sioux wooden horse effigy (390), full of blood, thunder and springy abandon, bear comparison with the Kansu horse?" Reviewers agreed. ${ }^{11}$ And while the maker was given as unknown, in the following decade, the piece, collected on Standing Rock and held by the South Dakota State Historical Society, started being attributed to No Two Horn, despite a vast discrepancy in style between this and other pieces of more ascertainable authorship. Although contested, this attribution increased interest in No Two Horn's work. Studies of his work and of horse effigies quickly followed on the footsteps of the London-Kansas City exhibitions, ${ }^{12}$ and in 1985 the North Dakota Historical society's Heritage Center itself brought its effigies out of its reserve and into its permanent display. Between 1976 and 1985, No Two Horn had risen postmortem to artist status and become available for inspiration.

The same time period also saw the rise of consultation, a process that would prove decisive in Butch's later career. Native American activism and lobbying, museum efforts at making their collections relevant to contemporary audiences, and, eventually, national legislation all made the presence of Native American experts in museums more and more common throughout the 1980s and 1990s. Descendants of No Two Horn himself were involved in such processes. While the most well-known act of the US Congress regulating consultation was the Native American Graves Protection and Repatriation Act of $1990,{ }^{13}$ Native American presence in museums was

10 Ralph T. Coe, The Responsive Eye: Ralph T. Coe and the Collecting of American Indian Art (New York and New Haven: The Metropolitan Museum of Art and Yale University Press, 2003), 15-16.

11 See Ralph T. Coe, Sacred Circles: Two Thousand Years of North American Indian Art (Kansas City: Nelson Gallery of Art, 1976), 9 and 168; and the review of the book by Helen H. Schuster in American Anthropologist, New Series, vol. 80, no. 1 (March 1978): 193-96, esp. 194.

12 For example, Ian M. West, “Tributes to a Horse Nation: Plains Indian Horse Effigies,” South Dakota History 9, no. 4 (1978): 291-302.

13 NAGPRA mandated the return of religious and funeral objects and human remains held in federal institutions to the peoples from whom they originated. Passed in 1990, it was only the most visible of a series of laws and regulations taken by the federal government that made consultation with recognized tribes mandatory in the fields of historic preservation, national parks, the environment, as well as general policy making. On NAGPRA and its effects, see C. Timothy McKeown, In the Smaller Scope of Conscience: The Struggle for National Repatriation Legislation, 1986-1900 (Tucson: University of Arizona Press, 2013); Tamara L. Bray and Thomas W. Killion, eds., Reckoning with the Dead: The Larsen Bay Repatriation and the Smithsonian Institution (Washington, DC: Smithsonian Institution 
hardly limited to repatriation. Beginning in the 1960s, many Native groups had sponsored projects aiming at reclaiming a lost or endangered heritage, most of the time defined as "cultural," with traditional arts and crafts foremost among those. These efforts were often entangled in the national and infra-national politics of commemoration. In public celebrations of the American past (such as the nation's bicentennial that saw the opening of "Sacred Circles"), acknowledging and symbolically repairing the damage colonization inflicted on Native people by making room for tribal representatives, dresses, and objects in museum exhibitions and functions became common. Active Native American participation in those ceremonies often took the form of "interpretation," as opposed to silent presence: no longer relics of a primitive past, Native American actors, artists, and tribal representatives, were asked to testify, as descendants, to the intentions and emotions of their ancestors, their intervention being regarded as promoting a more genuine understanding of the past. In this context, public institutions emphasized the protection of Native skills and techniques as part of the national heritage, while tribal authorities promoted their revival as a way to heal Native communities. Politically at odds, these logics were practically congruent. Navajo silversmithing, Haida basketry, and Pueblo pottery started being regarded as living traditions, to be protected and incorporated in new practices, art included. After the Japanese fashion, some of their practitioners were granted the status of living national treasures. The greater recognition accorded Indian art encouraged the development of specialized art fairs that loosened the grip tourism had had on the market so far and boosted consideration for "tribal art." Native artists thus found new opportunities for recognition and income, and new roles to fill as interpreters of tradition. They started evolving seamlessly between different art scenes, museums and fairs, reservation and off-reservation worlds. ${ }^{14}$

In these different but connected settings, Native artists' presence was predicated on the idea that they carried with them a specific type of knowledge. Yet all these contexts also contributed powerfully to shaping the very knowledge they promoted. Butch's career shows how. Butch had not attended a prestigious Indian arts school

Press, 1994); Ann M. Tweedie, Drawing Back Culture: The Makah Struggle for Repatriation (Seattle: University of Washington Press, 2002); Cara Krmpotich, The Force of Family: Repatriation, Kinship, and Memory on Haida Gwaii (Toronto: University of Toronto Press, 2014); and We Are Coming Home! Repatriation and the Restoration of Blackfoot Cultural Confidence, ed. Gerald T. Conaty (Edmonton, Alberta: Athabasca University Press, 2015).

14 On the rise of consultation in museums, see especially Ann McMullen, "The Currency of Consultation and Collaboration," Museum Anthropology Review 2, no. 2 (2008): 54-87; Gwyneira Isaac, "Mediating Knowledges: Zuni Negotiations for a Culturally Relevant Museum," Museum Anthropology 28, no. 1 (2005): 3-18; Ruth B. Phillips, “Community Collaboration in Exhibitions: Introduction,” in Museums and Source Communities, Laura Peers and Alison K. Brown, eds. (New York: Routledge, 2003), 157-70; Ann Fienup-Riordan, “Collaboration on Display: A Yup'ik Eskimo Exhibit at Three National Museums,” American Anthropologist 101, no. 2 (1999): 339-58. 


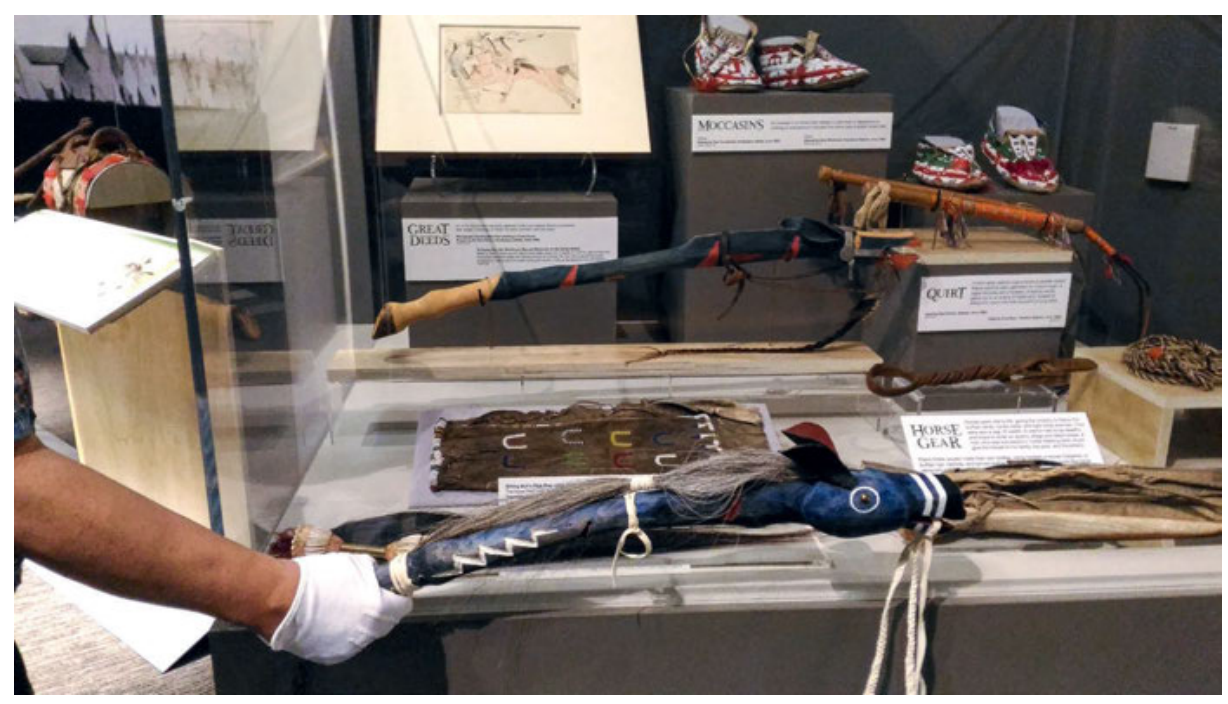

Fig. 2: Mark Halvorson, curator of collections research for the State Historical Society, holds one of Butch's effigies next to one of No Two Horn's in a display case at the museum.

such as the Institute of American Indian Arts of Santa Fe; he had not majored in art. Consequently, it took him close to twenty years to benefit from this configuration. His first public commissions date back to 1988, when the state of North Dakota prepared to celebrated its own centennial and ask him to the design "the Native people's North Dakota Centennial Logo." 15 Similarly, it is only in 1994 that Butch made his first three horse effigies after having started research on the cultural significance of this type of dancing sticks for teaching purposes. The market was receptive: all three effigies were immediately acquired by museum professionals. In keeping with his earlier experiences, this new phase of Butch's work was yet again predicated on his ability to make connections, this time between a dead artist and a very lively art scene centered on museum celebrations. Butch further developed his interest in and his own style of horse effigies through a close collaboration with Castle McLaughlin, who first came to North Dakota researching wild horses and eventually directed the Peabody Museum's celebration of the bicentennial of the Lewis and Clark Corps of Discovery's expedition in 2006. In 1999, one of his horse effigies was acquired by Peabody Museum, to be exhibited in its Hall of the North American Indian. Ten years later, with Castle McLaughlin, Butch cocurated Wiyohpiyata: Lakota Images of the Contested West an exhibition on Lakota drawings at the Peabody museum that again featured a horse

15 “Credits,” North Dakota Quarterly 56, no. 3 (Summer 1988): 367 
effigy by him. ${ }^{16}$ In the meantime, his work had been shown at the Thomas Jefferson House and the James Monroe House in Virginia. The Nelson-Atkins Museum, the very same Kansan institution that had first brought horse effigies into the limelight, had also acquired one of Butch's pieces. A chance encounter with McLaughlin in the 1980s, one centered on horses rather than art, finally made it possible for Butch to become an expert with access to a prestigious museum institution. This itinerary did not only allow him to become an heir of sorts for No Two Horn. It also put his art in general, and his horse effigies in particular, in a very specific configuration that yet again modified the way Butch mobilized and produced knowledge (fig. 2).

Hailing from the same community as No Two Horn and a Lakota like him, Butch first asked permission to make horse effigies from No Two Horn's grand-niece, whom he had interviewed several times since the 1970s. This was a formal gesture, a way to pay tribute to an elder, recognize her prior rights to No Two Horn's legacy, and prevent conflict. The visit, often emphasized in the press, ${ }^{17}$ was also a way for Butch to claim connection to someone who was not his relative, in a post-NAGPRA era where direct bloodline connection to former Native artists was strongly emphasized. ${ }^{18}$ But the research process that took him to museums more than to Standing Rock was not limited to symbolic, diplomatic gestures. Examining museum pieces (and the accompanying paperwork) to identify the material used for these "genuine" items constituted an essential part of the research process. As Butch explained it in our interviews, however, research went beyond identifying materials and techniques to include making an actual connection with the long-gone creators of these pieces. In 2001, on McLaughlin's recommendation, he was asked to produce with his United Tribes students weapons approximating those, now gone, that had adorned the entrance hall of Thomas Jefferson's house at Monticello, Virginia. Like other Native artists contacted for this exhibition, he was given an opportunity to examine old pieces held by the Peabody Museum of Archaeology and Ethnology at Harvard University and the North Dakota Heritage Center. ${ }^{19}$ Physical contact, touching the piece, was a way to connect

16 On Wiyohpiyata, see the Peabody's website, last accessed September 12, 2019, https://www.peabody.harvard.edu/lakota-images-of-the-contested-west.

17 See. Castle McLaughlin, "New Acquisition from the Contemporary American West: Sioux Carving," Symbols (Spring 1999): 17-18.

18 NAGPRA requires the repatriation of human remains or cultural items to descendants provided they can prove "a relationship of lineal descent." The emphasis on a restricted view of (biological) descent is not new in the world of Indian art. The Indian Arts and Crafts Act (first passed in 1935) already required that sellers of art labeled "Indian" or from a specific tribe, be able to demonstrate its authenticity by producing a certificate of tribal membership for the artist.

19 On Butch's work in the Monticello exhibition, see Castle McLaughlin, Hillel S. Burger, and Mike Cross, Arts of Diplomacy: Lewis and Clark's Indian Collection (Seattle: University of Washington Press and Cambridge, MA: Peabody Museum, 2003), 159. On Native artists' relationship with museum pieces, see Judith Ostrowitz, foreword by Nelson H. H. Graburn, Privileging the Past: Reconstructing History in Northwest Coast Art (Seattle: University of Washington Press, 1999). 
to it and through it, its maker. During our interviews, Butch also emphasized the possibility that objects would directly communicate with him. He made contact by prayer accompanied by proper offerings of tobacco and burning of sage. Contact could also be made in dreams. ${ }^{20}$

Butch's emphasis on protocol was not an idiosyncrasy of his, but one of the reasons he had been selected for collaboration with the Peabody and Monticello in the first place. In Castle McLaughlin's characterization, it's Butch's ease in the role of a cultural liaison that particularly recommended him for contact with pieces such as peace pipes and weapons, sacred and imbued with power-and for curators a public relations hazard in case they were mishandled and defiled. Butch's skill at reproducing them was always entangled with his knowledge of how to simply be around them. In the museum setting, the relational quality of pieces of Native craftsmanship was exacerbated. They connected staff and the public, museums and Native American tribes, contemporary artists with dead ones, and were held up as an opportunity for Americans to strike up new, potentially better relationships with Native Americans than they had done in the past. Museum pieces literally objectified a project to turn exhibitions into connection-making moments. ${ }^{21}$ And for those moments to be performed appropriately, there needed to be cultural interpreters like Butch.

This new role added yet another layer of knowledge and meaning to the horse effigies he was making. In the late 1990s and early 2000s, Butch made effigies for private individuals. But his work with museums changed the context in which they were understood, as well as the knowledge they were tied to. In North Dakota, Castle McLaughlin was part of a group that spearheaded the protection and promotion of a group of horses they identified as descendants of Indian ponies and a breed unto themselves, the Nokota. ${ }^{22}$ This project was closely tied to the efforts of tribal members on Standing Rock and elsewhere to promote contact with horses as a specific form of healing and education for youth and adults alike, because horses had been a nexus of Native cultures in the Plains, and because animals facilitated therapeutic efforts. ${ }^{23}$

20 On dreaming and Lakota crafts, see especially Hélène Wallaert, "Beads and a Vision: Waking Dreams and Induced Dreams as a Source of Knowledge for Beadwork Making. An Ethnographic Account from Sioux Country,” Plains Anthropologist 51, no. 197 (February 2006): 3-15; Arthur Amiotte, "Our Other Selves: The Lakota Dream experience," Parabola 6 (1982): 26-32; and Clark Wissler, "Some Protective Designs of the Dakota," Anthropological Papers of the American Museum of Natural History, vol. 5 (1907): 50.

21 See the video of the 2001 ceremony in North Dakota prior to the inauguration of the exhibition, Indian Nations Friendship Ceremony, C-Span, August 20, 2001, accessed July 6, 2021, https://www.c-span.org/video/?165701-1/indian-nations-friendship-ceremony.

22 On the Nokota horses, see the conservancy’s website, especially "Sioux Artists Feature Nokota® Horses in Lewis and Clark Bicentennial Project," Nokotahorse.org, last accessed September 12, 2019, https://www.nokotahorse.org/other-organizations.html.

23 Jen Janecek-Gartman, "Horse Culture is Focus Of UTTC Science Camp,” Tribal College Journal 20, no. 2 (Winter 2008), November 15, 2008, last accessed September 12, 2019, https://tribalcollegejournal. 
Butch took part in these programs, and he also incorporated Nokota hair in his horse effigies. He became an interpreter of traditional horse culture, on which his childhood and later work with Cannonball elders had made him conversant. At the Wiyohpiyata exhibition in 2009, the horse effigy he displayed was in turn repurposed. Not isolated as a work of art, but tied to a constellation of objects testifying to Lakota warrior culture, it was connected especially closely with the center piece of the exhibition: a ledger featuring war scenes drawn by nineteenth-century Lakota men. The blue color of Butch's effigy was intended as a direct gesture toward one of the horses prominent in the ledger-the blue roan color being considered a distinctive trait of the Nokota breed. ${ }^{24}$ In Wiyohpiyata, the horse effigy was not simply a modern take on an old practice. It epitomized the work of identification and reconstruction of the ledger's author and universe that structured the exhibit. Technically, the effigy might be little different from the one Butch had made ten years earlier for the Peabody. It was now socialized in a way that connected it no just to No Two Horn, but to other dead warriors, as well as living animals, and an art form: ledger art, in an effort at recreation that encompassed an entire branch of Lakota culture. A direct consequence of this for Butch was his taking up ledger art himself-and putting it on his team's jersey. ${ }^{25}$

Looking at Butch's career and his recreation of horse effigies, I have approached knowledge production and transmission in the world of tribal art as social and historical phenomena. I have reconstituted Butch's training and followed him in several social settings: the Standing Rock reservation, schools, and museums. While Butch himself relates his ability as an artist to a precise knowledge of material, techniques, and familiarity with genuine pieces, which he teaches and passes on, his itinerary also makes clear that he relied on more than recipes to become an artist. Fundamental in his development has been his ability to make connections. This is not simply a truism (you can learn anything from someone), but a historically-bound phenomenon. The migration of Native Americans off reservations, the migration of Native works into museum collections, the development of a tribal art market, the rise of collaboration with Native artists and consultants in museums, the creation of tribal art programs in Native institutions of higher learning: all these post-World War II developments

org/horse-culture-focus-uttc-science-camp/; and Dana Petersen, "College Fund Receives \$1 Million for Traditional Arts and Culture Preservation Program,” Tribal College Journal, April 7 2017, https:// tribalcollegejournal.org/college-fund-receives-1-million-traditional-arts-culture-preservation-program/uttc-horse-effigy-demonstration/.

24 Castle McLaughlin, “The Color of Thunder,” Symbols (Spring 2009): 4-11 and 18, esp. 18.

25 Ledger art developed throughout the Plains from the 1860s to the 1920s. On the pages of accounting books or even already printed books, Native artists, most of them warriors, depicted hunting and battle scenes in a style that evolved from hide painting. On ledger art, see especially Evan M. Maurer, The Native American Heritage: A Survey of North American Indian Art (Lincoln: University of Nebraska Press, 1977); and Castle Mclaughlin, A Lakota War Book from the Little Bighorn: The Pictographic "Autobiography of Half Moon" (Cambridge, MA: Peabody Museum Press, 2013). 
intensified the need for Native artists to display connections before their work could be taken seriously by professionals of the art world. This is due, in part, to the new sensitivity of representing Native American culture, which embedded Native artists and museum pieces in rituals and quasi-diplomatic interactions. Artists primarily defined as Indian or tribal were asked to behave as cultural intermediaries and interpreters. Their value was strongly correlated to their ability to act as conduits toward past and present Native communities and cultures. For Butch as for other tribal artists, it was, in this historical configuration, always about who you knew-before it was about what you knew. Becoming an artist was first about turning domestic and neighborly relations into credentials. But as I have tried to demonstrate, this configuration did more than enable or constrain Butch's activities, or encourage him to write his résumé with an emphasis on the place where he grew up. It continuously shaped the knowledge that he was basing his very activity on. His horse effigies are a case in point. He first studied them as museum pieces, for teaching purposes, after they had been made "available" as masterpieces of Lakota art. From the start, his making of horse effigies was part of a larger, collective project of preserving Lakota culture, that made the recreation of past artforms a self-conscious attempt to reconstitute knowledge and to display it in museums for educational purposes. In the back and forth between the classroom, the workshop, and the museum, Butch bridged the boundary between teacher and student, dead predecessor and living artist through a combination of knowledge-producing techniques: reading, examination, manipulation, prayer, and dreams. Objects themselves became imbued with relationships. As this world of knowledge and relationships evolved, so did the meaning of Butch's effigies, from homage to a belatedly recognized Lakota artist, No Two Horn, to a summary of Lakota horse culture. 
